\author{
O.V. Osadchuk, V.V. Martyniuk, T.I. Sydoruk, O.O. Semenova
}

\title{
Physical Parameters of the Synthesized Complex Compound of Cobalt (II) with N, N'-Bis(salicylidene)semicarbazide
}

\author{
Vinnytsia National Technical University, Vinnitsa, Ukraine, gyravl6@gmail.com
}

\begin{abstract}
A new material of strontium tetraaquad[N, N'-bis(salicylidene)semicarbazidatocobalt(II)] dihydrate (I) with the following composition: $\operatorname{Sr}\left[\mathrm{CoL}^{\prime}\left(\mathrm{H}_{2} \mathrm{O}\right)_{2}\right]_{2} \cdot 2 \mathrm{H}_{2} \mathrm{O}$, where $\mathrm{H}_{3} \mathrm{~L}=\mathrm{N}$,N'-bis(salicylidene)semicarbazide was synthesized. The molar mass of the extracted and dehydrated complex compound $\mathrm{Sr}\left[\mathrm{Co}\left(\mathrm{C}_{15} \mathrm{H}_{14} \mathrm{~N}_{3} \mathrm{O}_{5}\right)\right]_{2}$ is 838.07 $\mathrm{g} / \mathrm{mol}$, and the number of valence electrons in one molecule is 256 . A cylindrical sample with a mass of $0.09 \mathrm{~g}$ and a volume of $17.67 \cdot 10^{-9} \mathrm{~m}^{3}$ was utilized for experimental studies. Experimental measurements and theoretical calculations for main physical parameters of the synthesized material were performed. Such quantaties were calculated: the substance density $\rho=5,093 \cdot 10^{3} \mathrm{~kg} / \mathrm{m}^{3}$, the molecule mass $m_{0}=139,167 \cdot 10^{-26} \mathrm{~kg}$, the number of molecules in the test cylindrical sample $N_{m o l}=6,467 \cdot 10^{19}$ molec., the number of valence electrons $N=8,38 \cdot 10^{7}$, the bandgap $\Delta \mathrm{E}=0,78 e B$. Dependences of specific conductivity, current density, resistance, the Hall coeficient and charge carrier concentration on temperature were obtained.

Key words: induction, temperature, magnetic field, concentration, semiconductor, heterometallic complex compounds.
\end{abstract}

Received 16 October 2020; Accepted 15 December 2020.

\section{Introduction}

The purpose of the study is to develop a new sensor based on the synthesized heterometallic complex of strontium tetraaquad[N, N'bis(salicylidene)semicarbazidatocobaltate (II)] dihydrate.

It is known from [1-6] that the heterometallic complex compounds in solid compressed state have a wide range of electrically-conductive properties, which depend on features of a central atom, a heteroatom and chelating and bridging ligands and vary widely from dielectric to low impedance. In practical applications, the compounds can be used as semiconductor material for the thermistor manufacture.

\section{Theoretical and experimental studies}

In order to found out new heterometallic complex compounds with semiconductor properties, a method of synthesing the heterometallic complex of strontium tetraaquad

[N,N'-bis(salicylidene)semicarbazidatocobaltate(II)] dihydrate (I) with a composition of $\mathrm{Sr}\left[\mathrm{CoL}^{\prime}\left(\mathrm{H}_{2} \mathrm{O}\right)_{2}\right]_{2} \cdot 2 \mathrm{H}_{2} \mathrm{O}$, where $\mathrm{H}_{3} \mathrm{~L}=\mathrm{N}, \mathrm{N}^{\prime}-$ bis(salicylidene)semicarbazide was developed.

Synthesis of strontium tetraaquad [N, $N^{\prime}$ bis(salicylidene)semicarbazidatocobaltate(II)] dihydrate. A portion of $1.79 \mathrm{~g}(0.01 \mathrm{~mol})$ semicarbazone salicylic aldehyde was dissolved in $20 \mathrm{ml}$ of ethanol in a water bath $\left(\mathrm{t} \sim 60{ }^{\circ} \mathrm{C}\right)$. Then, $2.39 \mathrm{~g}(0.01 \mathrm{~mol})$ of $\mathrm{CoCl}_{2} \cdot 6 \mathrm{H}_{2} \mathrm{O}$ dissolved in $20 \mathrm{ml}$ of ethanol and $1.22 \mathrm{~g}(0.01 \mathrm{~mol})$ of salicylic aldehyde were added to the solution. The obtained mixture was heated to $60{ }^{\circ} \mathrm{C}$, kept in a water bath for 30-40 min and stirred intensively. A waterethanolic (1:1) solution of $\mathrm{Sr}(\mathrm{OH})_{2}$ was gradually added to the heated mixture $\left(\mathrm{t} \sim 60{ }^{\circ} \mathrm{C}\right)$ to $\mathrm{pH}=9-10$. The color of the reaction mixture was constantly changing from green $($ at $\mathrm{pH}=8$ ) to brown (at $\mathrm{pH}=10)$, the final fine crystalline precipitate formating. The reaction mixture was kept in a water bath for an hour, cooled, filtered in the Schott filter, washed thoroughly with cold ethanol, ether and dried in a desiccator with $\mathrm{CaCl}_{2}$ till the 
mass became constant at room temperature. A fine crystalline compound of brown color was obtained with a practical yield of $2.62 \mathrm{~g}$, which is $60 \%$ of calculated theoretically.

The extracted complex compound I is insoluble in water, benzene, chloroform, acetonitrile, ether, poorly soluble in aliphatic alcohols and acetone, soluble in DMF and DMSO.

Considering the data of elemental analysis and physical-chemical analsis research methods (X-ray phase analysis, IR-spectroscopy, conductometry, magnetochemistry, thermogravimetry), the composition of the heterometal coordination compound of cobalt (II) and strontium with N,N'-bis(salicylidene)semicarbazide was determined by the following chemical formula [7]:

$\mathrm{Sr}\left[\mathrm{CoL}^{\prime}\left(\mathrm{H}_{2} \mathrm{O}\right)_{2}\right]_{2} \cdot 2 \mathrm{H}_{2} \mathrm{O}$, where $\mathrm{L}^{\prime}=\mathrm{C}_{15} \mathrm{H}_{10} \mathrm{~N}_{3} \mathrm{O}_{3}$ or<smiles>[O-]C(/N=C/c1ccccc1[O-])=N/N=C/c1ccccc1[O-]</smiles>

The molar mass of the exacted and dehydrated complex compound $\mathrm{Sr}\left[\mathrm{Co}\left(\mathrm{C}_{15} \mathrm{H}_{14} \mathrm{~N}_{3} \mathrm{O}_{5}\right)\right]_{2}$ equals 838,07 $\mathrm{g} / \mathrm{mol}$, while the number of valence electrons in one molecule is 256 .

Since the synthesized heterometallic coordination compound of cobalt (II) and strontium with N, N'bis(salicylidene) semicarbazide contains water crystallization molecules, electrically-conductive properties were measured after having kept it in an oven at $105^{\circ} \mathrm{C}$ until the sample weight stopped changing.

Investigations of the electrically-conductive properties of compound I in the form of a compressed cylindrical sample showed that at the temperature of $20^{\circ} \mathrm{C}$ its specific resistivity was $8 \cdot 10^{12} \mathrm{Ohm} \cdot \mathrm{cm}$. Moreover, when the temperature increased from $20^{\circ} \mathrm{C}$ to $150{ }^{\circ} \mathrm{C}$ there was a typical for semiconductor materials rectilinear dependence between the specific resistivity $(\rho)$ and the temperature $(\mathrm{T})$. The calculated values of the temperature resistance coefficient (TCO) at $60{ }^{\circ} \mathrm{C}$ for the compound I $\left(-10.55 \% \mathrm{~K}^{-1}\right)$ and the sensitivity (B) of semiconductor materials $(9055 \mathrm{~K})$ substantiate that it is a semiconductor of medium sensitivity in the operating temperature range $20-150{ }^{\circ} \mathrm{C}$ in comparison with other similar materials [8].

Experimental studies were conducted in the temperature range from $293 \mathrm{~K}$ to $423 \mathrm{~K}$, on their base a mathematical model was obtained, which allowed modeling in a wider range from $273 \mathrm{~K}$ to $493 \mathrm{~K}$.

A cylindrical specimen with mass of $0.09 \mathrm{~g}$ and volume of $17.67 \cdot 10^{-9} \mathrm{~m}^{3}$, which was made of the dehydrated complex compound (I) by compression method, was used in experimental studies. The substance density was calculated considering these data by the formula (1):

$$
\rho=m / v=5,093 \cdot 10^{3} \mathrm{~kg} / \mathrm{m}^{3},
$$

where $\rho$ is the substance density; $m$ is the test sample mass; $V$ is the test sample volume.

Formula (2) was applied to calculate the mass of one molecule of the compound (I):

$$
m_{0}=M / N_{A}=139,167 \cdot 10^{-26} \mathrm{~kg},
$$

where $m_{0}$ is the mass of the compound's molecule; $N_{A}$ is the Avogadro number; $M$ is the molar mass of the compound (I).

The total number of molecules in the cylindrical test sample filled with the compound (I) was found from formula (3).

$$
N_{\text {mol }}=m / m_{0}=6,467 \cdot 10^{19} \text { molec. },
$$

where $N_{m o l}$ is the total number of molecules; $m_{0}$ is the mass of one molecule of the compound (I); $m$ is the mass of the test sample.

The number of valence electrons was determined by dividing the charge passing through the test cylinder per time unit by the electron charge (4):

$$
N=\frac{q_{\Sigma}}{q_{e}}=8,38 \cdot 10^{7} .
$$

The charge carrier concentration in the structure with sizes of $0.5 \times 0.5 \times 0.15 \mathrm{~mm}$ was calculated at the temperature of $373 \mathrm{~K}$ :

$$
n=N / V=2,3568 \cdot 10^{18} m^{-3} .
$$

The conducted studies of electrically-conductive properties for the synthesized, dehydrated and compressed strontium tetraaquad[N,N'bis(salicylidene)semicarbazidatocobaltate (II)] dihydrate in the temperature range of $293-423 \mathrm{~K}$ showed that its specific resistivity fell sharply from $8 \cdot 10^{10} \mathrm{Ohm} \cdot \mathrm{m}$ to $6 \cdot 10^{6} \mathrm{Ohm} \cdot \mathrm{m}$ with temperature rising, which was typical for semiconductor materials.

Experimental measurements enabled to calculate the specific conductivity of the material for these temperatures. For $\mathrm{T}_{1}=293 \mathrm{~K}$ we got $\sigma_{1}=12.5$. $10^{-12}(\mathrm{Ohm} \cdot \mathrm{m})^{-1}$, and for $\mathrm{T}_{2}=423 \mathrm{~K}$ we got $\sigma_{2}=16.6$. $10^{-8}(\mathrm{Ohm} \cdot \mathrm{m})^{-1}$. These experimental studies enabled to find out the width of the bandgap:

$$
\Delta \mathrm{E}=\frac{k \ln \frac{\sigma_{1}}{\sigma_{2}}}{\left(\frac{1}{T_{2}}-\frac{1}{T_{1}}\right)}=1,249 \cdot 10^{-19} \mathrm{~J}=0,78 \mathrm{eB},
$$

where $\mathrm{T}$ is the absolute temperature; $\sigma$ is the specific conductivity of the material; $\mathrm{k}$ is the Boltzmann constant.

The calculations proved that the material was a semiconductor [9].

Dependence of the specific conductivity on temperature was calculated considering the bandgap of the material and experimental data [10]. The graph of the logarithmic dependence of the conductivity on temperature is shown in Fig. 1.

Fig.1 demonstrates that the structure's specific conductivity increases from $1.3 \cdot 10^{-12}(\mathrm{Ohm} \cdot \mathrm{m})^{-1}$ to $3.46 \cdot 10^{-6}(\mathrm{Ohm} \cdot \mathrm{m})^{-1}$, with temperature increasing from $273 \mathrm{~K}$ to $493 \mathrm{~K}$.

Fig. 2 demonstrates the material's specific resistivity changing with the temperature.

The graph illustrates that the specific resistivity falls from $7.69 \cdot 10^{11} \mathrm{Ohm} \cdot \mathrm{m}$ to $2.88 \cdot 10^{5} \mathrm{Ohm} \cdot \mathrm{m}$.

Fig. 3 illustrates the dependence of resistance on temperature for the semiconductor with sisez $0.5 \times 0.5 \times$ $0.15 \mathrm{~mm}$. 
Physical Parameters of the Synthesized Complex Compound...

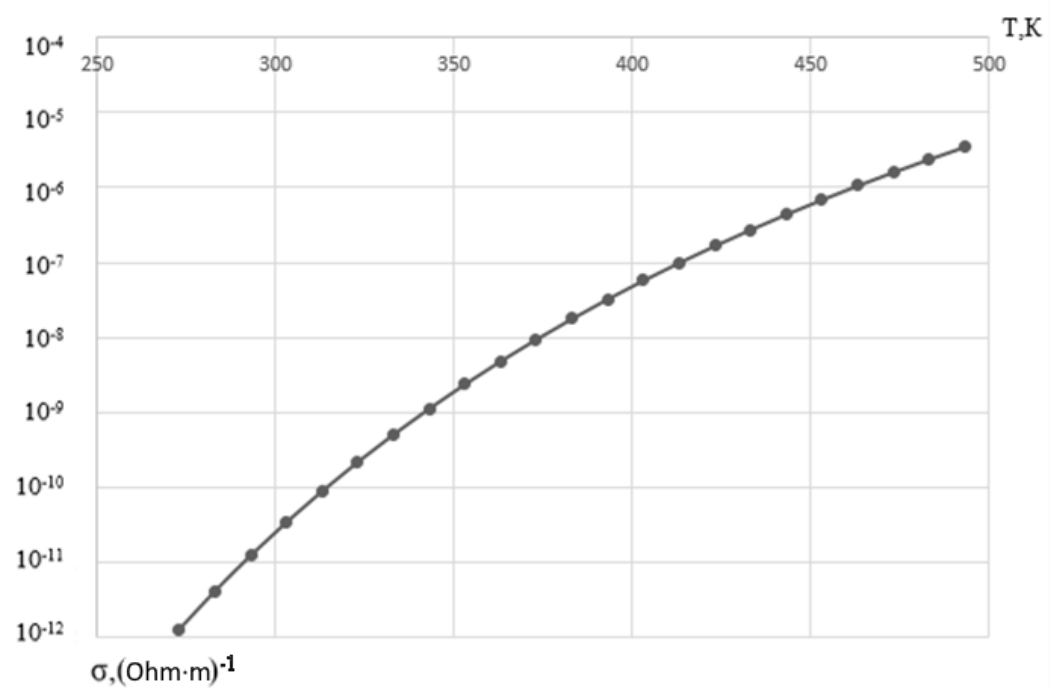

Fig. 1. Logarithmic dependence of the material specific conductivity on temperature.

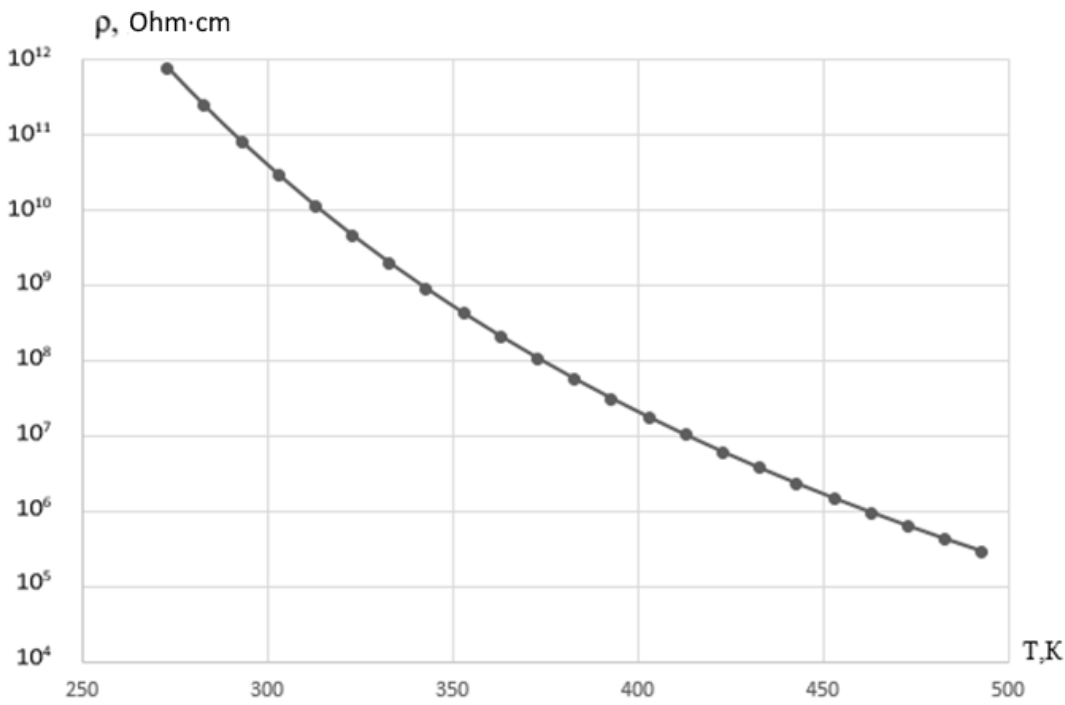

Fig. 2. Logarithmic dependence of the specific resistivity on temperature,

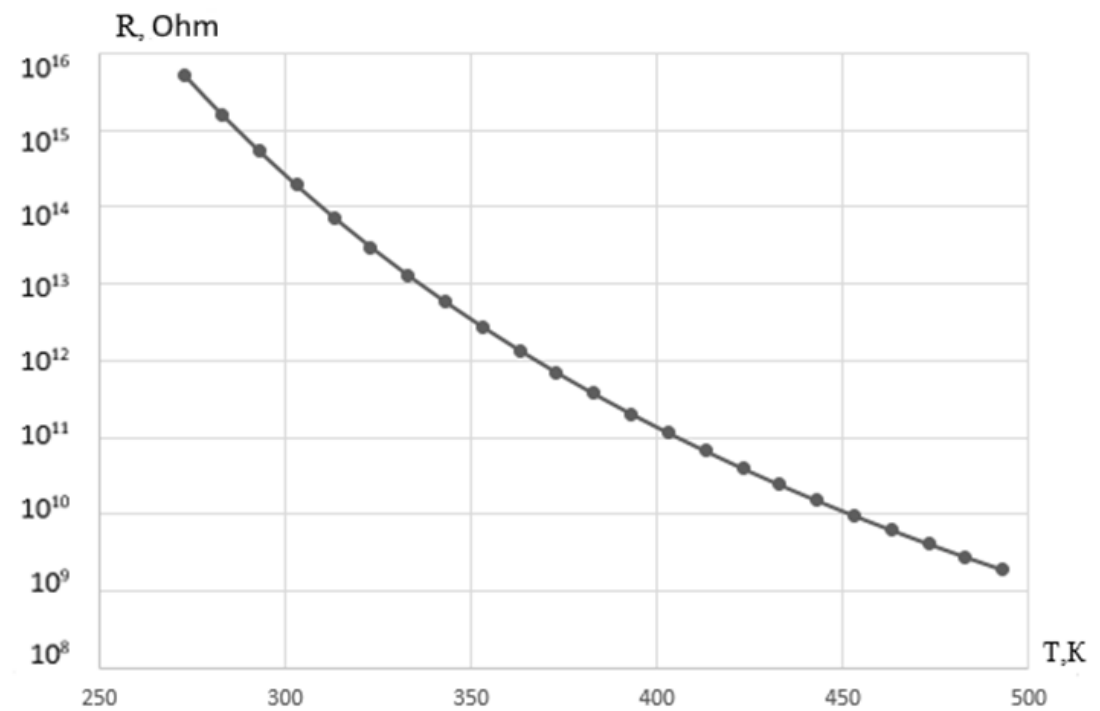

Fig. 3. Logarithmic dependence of the material resistance on temperature. 
The figure shows that the material's resistance falls from $5.127 \cdot 10^{15} \mathrm{Ohm}$ at the temperature of $273 \mathrm{~K}$ to $1.92 \cdot 10^{9} \mathrm{Ohm}$ at the temperature of $493 \mathrm{~K}$.

Fig. 4 demonstrates the dependence of the current on temperature.

The graph shows that the current through the cylinder varies from $1.95 \cdot 10^{-15} \mathrm{~A}$ to $5.19 \cdot 10^{-9} \mathrm{~A}$ at the supply voltage of $10 \mathrm{~V}$.

Fig. 5 illustrates the logarithmic dependence of current density on temperature at the supply voltage of $10 \mathrm{~V}$.

The graph illustrates that the current density rises by 6 orders of magnitude from $2.6 \cdot 10^{-8} \mathrm{~A} / \mathrm{m}$ to $6.9 \cdot 10^{-2} \mathrm{~A} / \mathrm{m}$ in

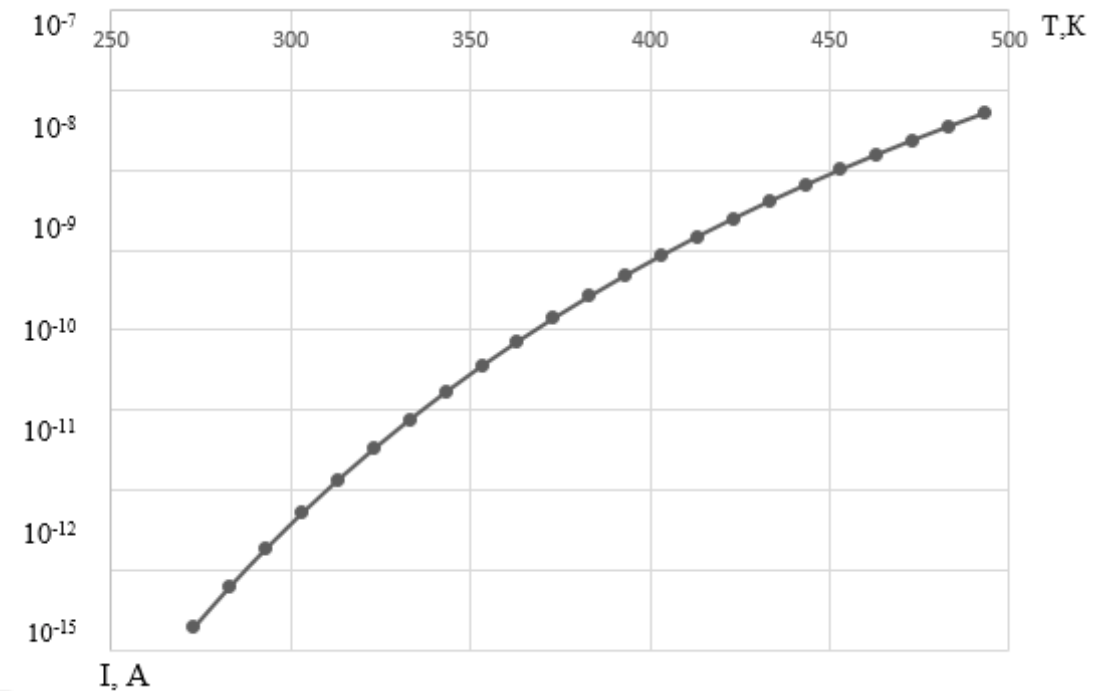

Fig. 4. Logarithmic dependence of the current on temperature.

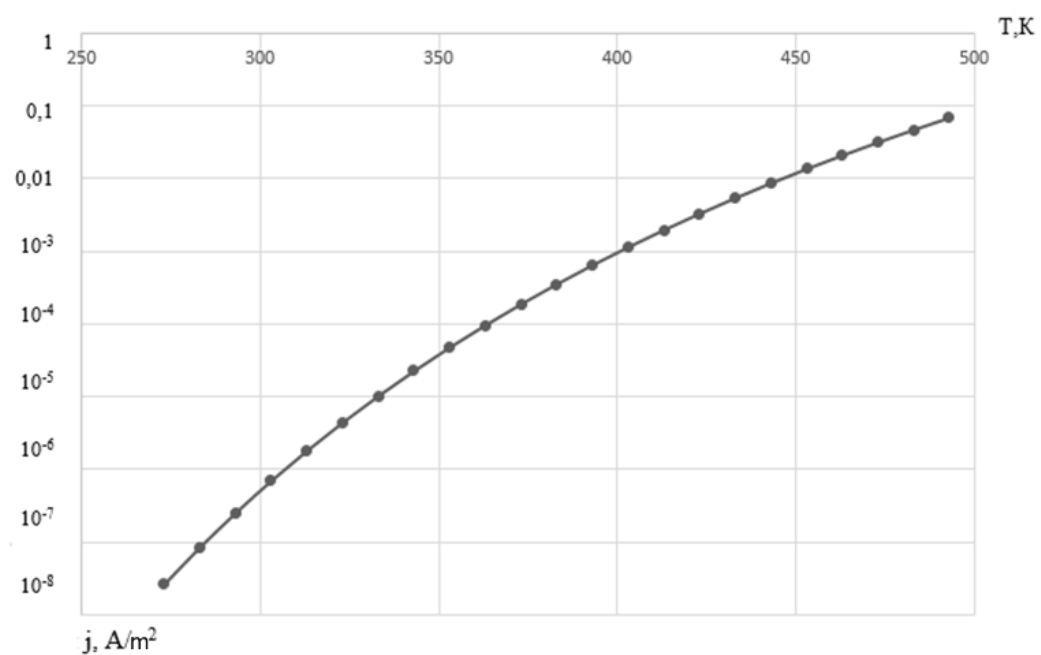

Fig. 5. Logarithmic dependence of the current density on temperature.

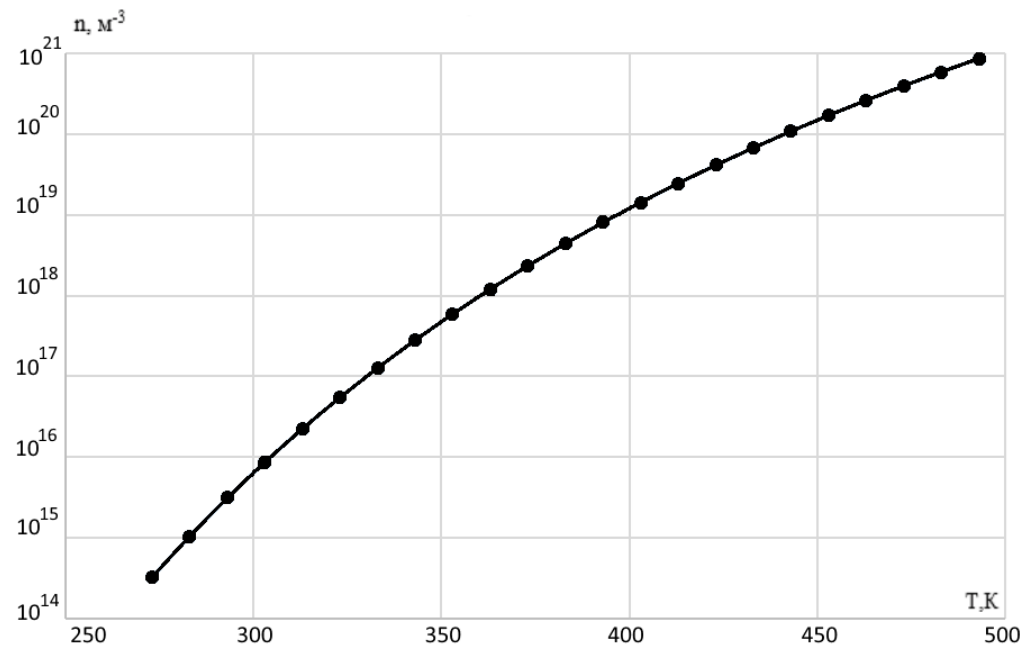

Fig. 6. Logarithmic dependence of the concentration of charge carriers on temperature. 
the temperature range from $273 \mathrm{~K}$ to $493 \mathrm{~K}$.

Calculating the bandgap and the dependence of the semiconductor's charge carrier concentration on temperature provides a graph of the charge carrier concentration dependence on temperature, presented in logarithmic form in Fig. 6.

Fig. 6 shows the charge carrier concentration rising from $3.25 \cdot 10^{14} \mathrm{~m}^{-3}$ to $8.66 \cdot 10^{20} \mathrm{~m}^{-3}$ in the temperature range from $273 \mathrm{~K}$ to $493 \mathrm{~K}$.

Calculation of the Hall coefficient at $373 \mathrm{~K}$ provided the following results:

$$
R_{H}=1 / n q=2,66 m^{3} \cdot C^{-1},
$$

where $\mathrm{q}$ is the electron charge; $\mathrm{n}$ is the charge carrier concentration.

The quantum Hall coefficient was calculated by formula (8):

$$
R_{q H}=-3 \pi / 8 n q=3,12 m^{3} \cdot C^{-1} .
$$

Having combined the equation of the charge carrier concentration dependence on temperature and formula (8), we get the Hall coefficient dependence on temperature (9):

$$
R_{q H}=-\frac{3 \pi}{8 q n_{0}} \cdot e^{\frac{\Delta \mathrm{E}}{k T}} .
$$

A logarithmic dependence of the quantum Hall coefficient on temperature was obtained by applying this formula:

The graph in Fig. 7 shows the value of the quantum Hall coefficient for this complex compound falling from $2.26 \cdot 10^{4} \mathrm{~m}^{3} \cdot \mathrm{C}^{-1}$ to $8.49 \cdot 10^{-3} \mathrm{~m}^{3} \cdot \mathrm{C}^{-1}$ with temperature rising from 273 to $493 \mathrm{~K}$.

The mobility of charge carriers for a quantum case is:

$\mu_{n}=R_{q H} \cdot \sigma=2,94 \cdot 10^{-8} \mathrm{~m}^{3} \cdot(B \cdot c)^{-1}$.

Substitution of the dependence of the specific conductivity and the Hall coefficient on temperature into (10) proved that the mobility of charge carriers did not

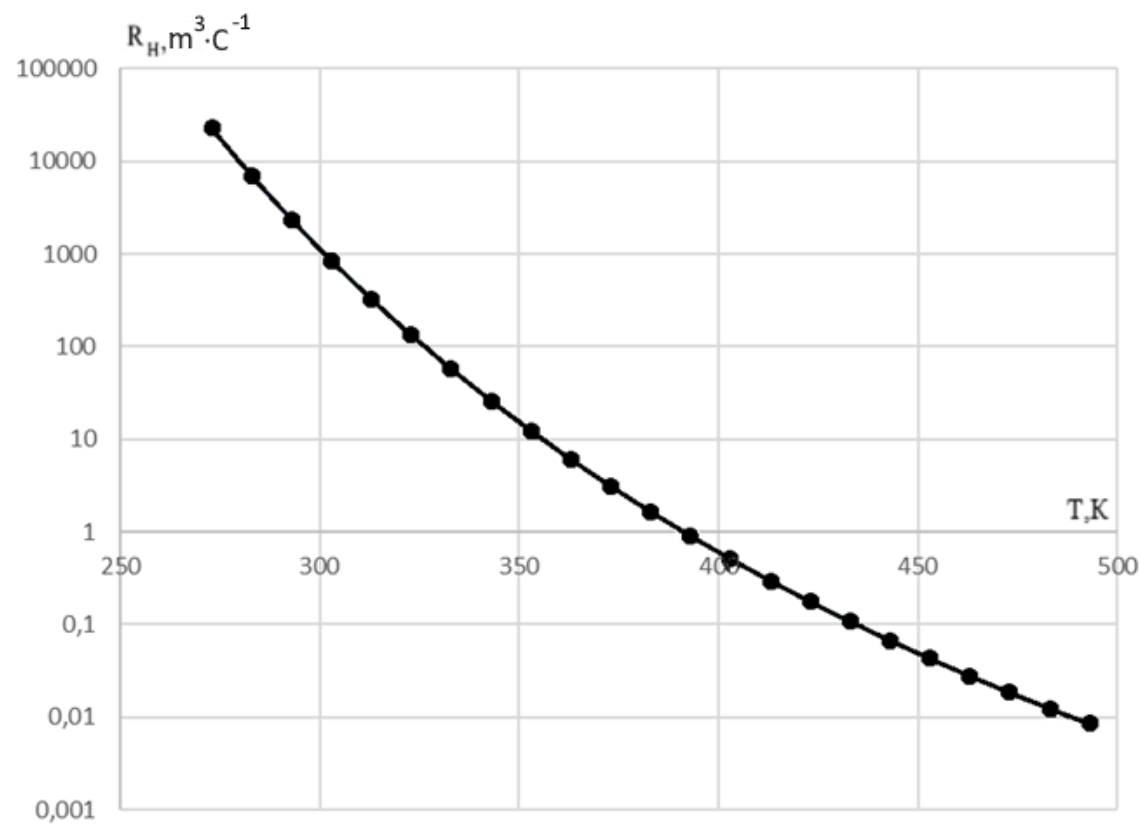

Fig. 7. Logarithmic dependence of the quantum Hall coefficient on temperature.

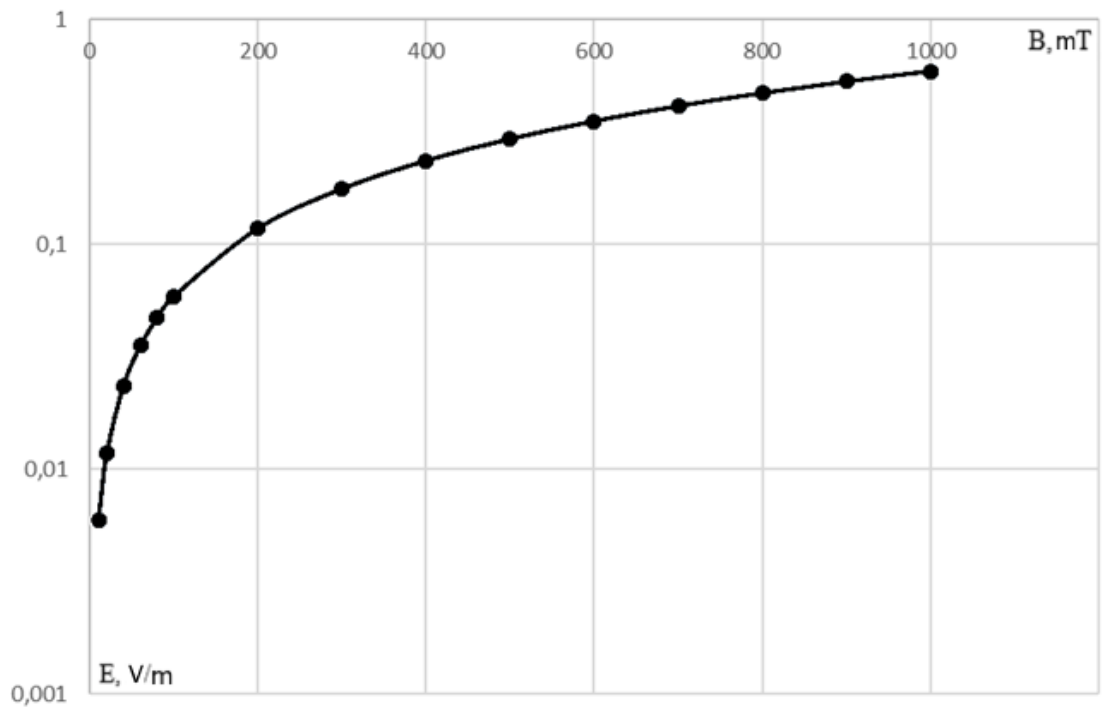

Fig. 8. Logarithmic dependence of the electric field strength in the semiconductor on the magnetic field induction. 


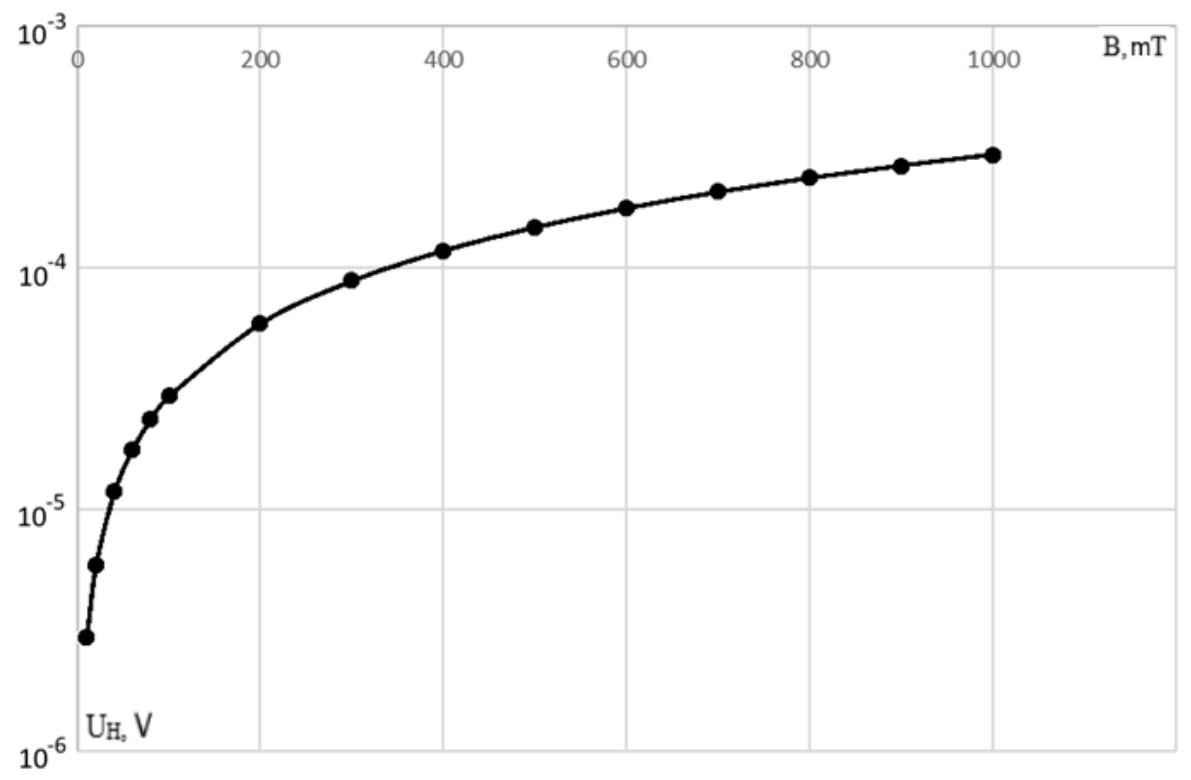

Fig. 9. Logarithmic dependence of the Hall voltage on the magnetic field induction.

depend on temperature.

Figure 8 shows calculation of the Hall voltage dependences for the electric field in the semiconductor with sizes $0.5 \times 0.5 \times 0.15 \mathrm{~mm}$ under action of the magnetic field in the semiconductor.

Fig. 8 illustrates the voltage rising from $5.8 \cdot 10^{-3}$ to $0.58 \mathrm{~V} / \mathrm{m}$ in the range from 10 to $1000 \mathrm{mT}$.

The logarithmic dependence of the Hall voltage on the magnetic field induction for the studied compound is presented in Fig. 9.

The graph illustrates the Hall voltage rising from $2.94 \cdot 10^{-6}$ to $2.94 \cdot 10^{-5} \mathrm{~V}$ in the range from 10 to $100 \mathrm{mT}$; from $2.94 \cdot 10^{-5} \mathrm{~V}$ to $1.17 \cdot 10^{-4} \mathrm{~V}$ in the range from 100 to $400 \mathrm{mT}$, and from $1.17 \cdot 10^{-4}$ to $2.94 \cdot 10^{-4} \mathrm{~V}$ in the range from $400 \mathrm{mT}$ to $1000 \mathrm{mT}$.

\section{Conclusions}

A new sensitive element based on the synthesized heterometallic complex compound of strontium tetraaquad[N,N'-

bis(salicylidene)semicarbazidatocobaltate (II)] dihydrate has been developed. The method of synthesizing this material is given and the influence of temperature and magnetic field on physical properties of this semiconductor is investigated.

The investigation of electrically-conductive properties for the synthesized material in compressed form at the temperature range of $273-493 \mathrm{~K}$ has demonstrated that its bandgap was $0.78 \mathrm{eB}$ and its specific resistivity fell sharply from $7.69 \cdot 10^{11} \mathrm{Ohm} \cdot \mathrm{m}$ to $2.88 \cdot 10^{5} \cdot \mathrm{Ohm} \cdot \mathrm{m}$ with temperature rising, which was typical for semiconductor materials. The chemical compound starts to decompose from $523 \mathrm{~K}$, the charge carrier concentration rises from $3.25 \cdot 10^{14} \mathrm{~m}^{-3}$ at $273 \mathrm{~K}$ to $8.66 \cdot 10^{20} \mathrm{~m}^{-3}$ at $493 \mathrm{~K}$, while the Hall coefficient falls from $2.26 \cdot 10^{4} \mathrm{~m}^{3} \cdot \mathrm{C}^{-1}$ to $8.49 \cdot 10^{-3} \mathrm{~m}^{3} \quad \mathrm{C}^{-1}$ with temperature rising from $273 \mathrm{~K}$ to $493 \mathrm{~K}$, the Hall voltage varies from $2.94 \cdot 10^{-6}$ to $2.94 \cdot 10^{-4} \mathrm{~V}$ in the magnetic field range from 0 to $1000 \mathrm{mT}$.

Osadchuk O.V. - Professor, Doctor of Technical Sciences, Head of the Department of Radio Engineering; Martyniuk V.V. - Ph.D, Associate Professor of Electronics and Nanosystems;

Sydoruk T.I. - Ph.D, Associate Professor of Chemistry and Chemical Technology;

Semenova O.O. - Ph.D, Associate Professor of Telecommunications Systems and Television.

[1] M.A.Redayan, Baghdad Science Journal 9(3), 532 (2012) (doi: https://doi.org/10.21123/bsj.2012.9.3.532-540).

[2] L.W. Xue, X.W. Li, G.Q. Zhao, W.C. Yang, Russian J. of Coord. Chem. 39(12), 872 (2013) (doi: https://doi.org/10.1134/S1070328413110092).

[3] A.A. Vashchenko, L.S. Lepnev, A.G. Vitukhnovskii et al., Optics and Spectroscopy 108(3), 463 (2010) (doi: https://doi.org/10.1134/S0030400X10030227).

[4] N.V. Gerbeleu, V.B. Arion, Template synthesis of macrocyclic compounds (Shtiintsa, Kishinev, 1990).

[5] A.V. Pardhi, A.D. Bansod, A.R. Yaul, A.S. Aswar, Journal of Coordination Chemistry 36(4), 298 (2010) (doi: https://doi.org/10.1134/S107032841004010X).

[6] I.V. Shabanova, T.P. Storozhenko, V.I. Zelenov et al., Ecological Bulletin of Research Centers of the Black Sea Economic Cooperation 3, 91 (2004).

[7] A.P. Ranskyy, M.V. Yevsyeyeva, T I. Panchenko, O.A. Hordiyenko, Ukrainian chemistry journal 79(2), 74 (2013) (http://nbuv.gov.ua/UJRN/UKhJh_2013 79_1-2_16). 
[8] T. Panchenko, M. Evseeva, A. Ranskiy, Chem. \& Chem. Technology 8(3), 243 (2014).

[9] O. Osadchuk, V. Martyniuk, I. Osadchuk et al., 2020 IEEE 15th International Conference on Advanced Trends in Radioelectronics, Telecommunications and Computer Engineering (TCSET) (Lviv-Slavske, Ukraine, 2020). P. 511 (doi: 10.1109/TCSET49122.2020.235485).

[10] O.V. Osadchuk, V.V. Martynyuk, M.V. Yevsyeyeva, O.O. Seletska, Herald of Khmelnytskyi national university (3), 97 (2019).

[11] O.V. Osadchuk, V.V. Martynyuk, M.V. Yevsyeyeva, O.O. Seletska, Visnyk of Vinnytsia Polytechnical Institute4(145), 80 (2019).

[12] O.V. Osadchuk, V.V. Martynyuk, T.I. Sydoruk, M.V. Yevsyeyeva, Herald of Khmelnytskyi national university 5, 169 (2019).

\title{
О.В. Осадчук, В.В. Мартинюк, Т.І. Сидорук, О.О. Семенова
}

\section{Фізичні параметри синтезованої комплексної сполуки кобальту(II) 3 n,n'-біс(саліциліден)семикарбазидом}

\author{
Вінниџький національний технічний університет, Вінниия, Україна, gyravl6@ gmail.com
}

\begin{abstract}
Синтезовано новий матеріал стронцій тетрааквади[N,N'біс(саліциліден)семикарбазидатокобальтат(II)] дигідрат (I) такого складу: $\operatorname{Sr}\left[\mathrm{CoL}^{\prime}\left(\mathrm{H}_{2} \mathrm{O}\right)_{2}\right]_{2} \cdot 2 \mathrm{H}_{2} \mathrm{O}$, де $\mathrm{H}_{3} \mathrm{~L}=\mathrm{N}, \mathrm{N}$-біс (саліциліден)семикарбазид.

Молярна маса виділеної та зневодненої комплексної сполуки $\operatorname{Sr}\left[\mathrm{Co}_{(}\left(\mathrm{C}_{15} \mathrm{H}_{14} \mathrm{~N}_{3} \mathrm{O}_{5}\right)\right]_{2}$ дорівнює 838,07 г/моль, а кількість валентних електронів в одній молекулі - 256. Для проведення експериментальних досліджень використовували циліндричний зразок масою 0,09 г та об'ємом $17,67 \cdot 10^{-9} \mathrm{M}^{3}$.

Проведено експериментальні вимірювання та теоретичні розрахунки основних фізичних параметрів даного синтезованого матеріалу. Розраховано густину речовини $\rho=5,093 \cdot 10^{3} \kappa 2 / \mu^{3}$, масу однієї молекули $m_{0}=139,167 \cdot 10^{-26}$ к2, кількість молекул в об'ємі досліджуваного циліндричного зразка $N_{\text {мол }}=6,467 \cdot 10^{19}$ молек., кількість валентних електронів $N=8,38 \cdot 10^{7}$, ширину забороненої зони $\Delta \mathrm{E}=0,78 e B$. Доведено, що даний матеріал $\epsilon$ напівпровідником. Отримано залежності питомої провідності, густини струму, опору, сталої Холла та концентрації носіїв заряду від температури.

Ключові слова: індукція, температура, магнітне поле, концентрація, напівпровідник, гетерометалічні комплекні сполуки.
\end{abstract}

